\title{
PENGARUH PEMBERIAN KONSELING KB TERHADAP PEMILIHAN KONTRASEPSI JANGKA PANJANG (MKJP) DI KELURAHAN BELAWAN BAHAGIA TAHUN 2018
}

\author{
Resy Tesya Mulianda ${ }^{1}$, Destyna Yohana Gultom ${ }^{2}$ \\ STIKes Imelda Medan, Indonesia
}

\section{Article Info}

Keywords:

Material

Media

Methods

Counseling

MKJP

\begin{abstract}
Family Planning Program (KB) is one of the programs to reduce maternal mortality and reduce population growth. Understanding MKJP (long-term contraceptive method) is a contraceptive that can be used for a long period of time, more than two years, effective and efficient for the purpose of spacing more than 3 years of birth or to terminate a pregnancy in a partner who does not want to add more children. The purpose of this study was to determine how the effect of family planning counseling by family planning field officers (PLKB) on mothers in the selection of long-term contraceptive methods (MKJP) in Belawan Bahagia Village in 2018. This study is an analytic study, with observational research with look for influence between variables and do an analysis of the data collected and how much the relationship between variables and use primary data and secondary data. This study uses a cross-sectional design as a research design. The population in this study were all active family planning participants who lived in Belawan Bahagia Subdistrict, Medan Belawan Subdistrict, Madya City, Medan with a total of 1245 people, then the drawing technique was carried out until 166 samples were obtained. The results of the study found that the selection of materials and media for good counseling, as well as the majority of methods using the Long-Term Contraception Method (MKJP). There is material influence, media and counseling method on MKJP with p.value $<0.05$.
\end{abstract}

This is an open access article under the CC BY-SAlicense.

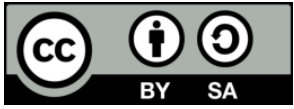

Corresponding Author:

Resy Tesya Mulianda,

Program Studi D-III Kebidanan,

STIKes Imelda Medan,

Jl. Bilal No. 52 Kelurahan Pulo Brayan Darat I Kecamatan Medan Timur, Medan - Sumatera Utara.

Email: resy_tesya@yahoo.co.id

\section{INTRODUCTION}

Laju pertumbuhan penduduk dan meningkatnya angka kelahiran menjadi masalah yang membutuhkan perhatian. Saat ini ada sebuah dilemma kontroversi yang terjadi dalam kesehatan ibu dan anak. Salah satu program pemerintah yang menjamin kesejahtraan ibu hamil dengan memberikan bantuan dana sosial, justru telah menjadi jerat menggagalkan program BKKBN tentang keluarga berencana. Bahkan pada beberapa kasus ditemukan ibu dengan usia risiko tinggi diatas 40 tahun sengaja hamil hanya untuk 
mendapatkan bantuan dana sosial dari pemerintah. Laju Pertumbuhan Penduduk (LPP) pada periode tahun 1980-1990 adalah 1,97\%, tahun 1990-2000 turun menjadi 1,45\% dan tahun 2000-2006 turun lagi menjadi 1,34\% dan naik lagi pada tahun 2010 yaitu 1,49\%. Total Fertility Rate (TFR) tahun 1971 adalah 5,5 per Pasangan Usia Subur (PUS), tahun 1980-1990 turun menjadi 2,34 dan pada tahun 2000-2005 turun lagi menjadi 2,28. Angka ini menunjukkan penurunan TFR dari waktu ke waktu tetapi belum mencapai target nasional yaitu 2,1. Dari pertumbuhan jumlah penduduk ini tentu saja akan berimplikasi secara signifikan terhadap perkembangan ekonomi dan kesejahteraan Negara. (BKKBN, 2010). Untuk itu diperlukan upaya dan langkah konkrit guna menurunkan laju pertumbuhan penduduk melalui berbagai program baik dari aspek kualitas maupun kuantitas (Kementrian Koordinator Bidang Kesejahteraan Rakyat, 2013).

Badan kependudukan dan Keluarga Berencana Nasional (BKKBN) sedang menerapkan kontrasepsi jangka panjang (MKJP) yang dinilai jauh lebih efektif dalam menekan angka kelahiran yang menjadi unggulan dalam mendukung program kelurga berencana. Berdasarkan SDKI 2012 menunjukkan pemakaian alat kontrasepsi pil mengalami kenaikan 5 persen pada tahun 2007 meningkat menjadi 11 persen pada tahun 2012. Sementara penggunaan IUD mengalami penurunan dari 8 persen pada tahun 1991 terus mengalami penurunan hingga menjadi 2 persen ditahun 2012. Pemakaian suntik mengalami kenaikan dari 7 persen ditahun 1991 menjadi 18 persen ditahun 2012. Peningkatan yang relative kecil terjadi pada penggunaan implant yang hanya mengalami kenaikan sebesar 2 persen selama periode 21 tahun (BKKBN, 2012).

Hasil pelaksanaan sub sistem pencatatan dan pelaporan BKKBN bulan Juni 2012 bahwa Peserta KB Baru secara Nasional sampai dengan bulan Juni 2012 sebanyak 4.587 .909 peserta. Apabila dilihat dari persentasenya adalah 355.973 peserta IUD (7,76\%), 69.816 peserta MOW (1,52\%), 14.030 peserta MOP $(0,31 \%), 323.652$ peserta Kondom (7,05\%), 434.222 peserta Implant (9,46\%), 2.186.033 peserta Suntikan (47,65\%), dan 1.204.183 peserta Pil (26,25\%). Mayoritas peserta KB baru bulan Juni 2012, didominasi oleh peserta KB yang menggunakan Non Metode Kontrasepsi Jangka Panjang (Non MKJP), yaitu sebesar 80,95\% dari seluruh peserta KB. Sedangkan peserta KB baru yang menggunakan metode jangka panjang seperti IUD, MOW, MOP dan Implant hanya sebesar 19,05\% (BKKBN, 2012). Berdasarkan survey awal yang dilakukan di Desa Belawan Bahagia maka penulis tertarik untuk melakukan penelitin yang berjudul Pengaruh pemberian konseling KB oleh Petugas Lapangan Keluarga Berencana (PLKB) terhadap ibu dalam pemilihan metode kontrasepsi jangka panjang (MKJP) di Kelurahan Belawan Bahagia.

\section{RESEARCH METHOD}

Penelitian ini termasuk penelitian studi analitik, dengan jenis penelitian observasional. Penelitian observasional analitik dimana peneliti mencari hubungan antar variabel dan dilakukan analisis terhadap data yang dikumpulkan dan seberapa besar hubungan antar variabel yang ada. Penelitian ini menggunakan data primer dan juga data sekunder. Penelitian ini menggunakan rancangan Cross Sectional sebagai rancangan penelitian.

Penelitian ini dilakukan di Kelurahan Belawan Bahagia. Penelitian dilaksanakan mulai bulan September 2018. Pemilihan lokasi dikarenakan pada Kecamatan Belawan petugas lapangan KB (PLKB) aktif untuk melakukan konseling kepada akseptor KB tetapi selama tiga tahun terakhir Kecamatan Belawan berada pada posisi 12 dari 21 kecamatan di Kota Medan.

Populasi dalam penelitian ini adalah semua peserta KB aktif yang bertempat tinggal di Kelurahan Belawan Bahagia Kecamatan Medan Belawan Kota Madya Medan dengan jumlah populasi dalam penelitian ini adalah 1245 orang, kemudian dilakukan tehnik pengundian hanya satu kali untuk menentukan unsur pertama dari sampling yang akan diambildan didapatnomor sampel pertama adalah nomor urut 4, maka nomor selanjutnya adalah no 12, 20, 28 dan seterusnya sampai didapat jumlah sampel 166 sampel. Variabel independen dalam penelitian ini adalah materi konseling, media konseling, metode konseling. Variabel dependen yaitu pemilihan metode kontrasepsi Jangka Panjang.

DefinisiOperasional:

1. Materi konseling yaitu bahan-bahan konseling mengenai alat kontrasepsi MKJP yang diberikan Petugas Lapangan Keluarga Berencana (PLKB) terhadap akseptor KB.

2. Media konseling dimana PLKB menggunakan media untuk memberikan informasi tentang alat- alat kontrasepsi MKJP terhadap akseptor KB.

3. Metode konseling apakah yang diberikan oleh PLKB kepada akseptor KB tentang alat-alat kontrasepsi MKJP.

4. Pemilihan Metode Kontrasepsi Jangka Panjang dimana pilihan kontrasepsi yang ditentukan oleh akseptor KB apakah menggunakan MKJP (AKBK, AKDR, MOW) atau non-MKJP (Suntik).

Analisis univariat dilakukan untuk mendapatkan gambaran tentang distribusi frekuensi masingmasing variabel independen yang meliputi materi konseling, media konseling, metode konseling dengan variabel dependen yaitu pemilihan metode kontrasepsi jangka panjang (MKJP). Pengolahan data meliputi 
tahap editing atas data yang telah tersedia, tahap pengkodean dan penilaian (coding and scoring), serta tahap entri data kedalam tabel pengukuran. Data kemudian dimasukkan dan dianalisis menggunakan program SPSS, dan dilakukan uji normalitas. Uji hipotesis yang digunakan dalam penelitian ini adalah uji $\mathrm{t}$ berpasangan (pairedttest).

\section{RESULTS AND ANALYSIS}

Tabel 1. Tabulasi Silang Pengaruh Materi Konseling Terhadap Ibu Dalam Pemilihan Metode Kontrasepsi Jangka Panjang Di Kelurahan Belawan Bahagia Tahun 2018

\begin{tabular}{|c|c|c|c|c|c|c|c|c|}
\hline \multirow{3}{*}{ No } & \multirow{3}{*}{$\begin{array}{c}\text { Materi } \\
\text { Konseling }\end{array}$} & \multicolumn{4}{|c|}{ Pemilihan KB } & \multirow{2}{*}{\multicolumn{2}{|c|}{ Total }} & \multirow{3}{*}{$p$ value } \\
\hline & & \multicolumn{4}{|c|}{ Tidak Menggunakan MKJP Menggunakan MKJP } & & & \\
\hline & & $\mathrm{n}$ & $\%$ & n & $\%$ & n & $\%$ & \\
\hline 1 & Kurang Baik & 40 & 67,8 & 19 & 32,2 & 59 & 100 & \multirow{3}{*}{0,03} \\
\hline 2 & Baik & 16 & 15.0 & 91 & 85.0 & 107 & 100 & \\
\hline & Total & 56 & 33.7 & 110 & 66.3 & 166 & & \\
\hline
\end{tabular}

Dari tabel dilihat bahwa materi konseling yang baik mayoritas $85 \%$ menggunakan metode kontrasepsi jangka panjang.

Tabel 2. Tabulasi Silang Pengaruh Media Konseling Terhadap Ibu Dalam Pemilihan Metode Kontrasepsi Jangka Panjang Di Kelurahan Belawan Bahagia Tahun 2018

\begin{tabular}{|c|c|c|c|c|c|c|c|c|}
\hline \multirow{3}{*}{ No } & \multirow{3}{*}{$\begin{array}{c}\text { Media } \\
\text { Konseling }\end{array}$} & \multicolumn{4}{|c|}{ Pemilihan KB } & \multirow{2}{*}{\multicolumn{2}{|c|}{ Total }} & \multirow{3}{*}{ p value } \\
\hline & & \multicolumn{2}{|c|}{ Tidak Menggunakan MKJP } & \multicolumn{2}{|c|}{ Menggunakan MKJP } & & & \\
\hline & & $\mathbf{n}$ & $\%$ & $\mathbf{n}$ & $\%$ & $\mathbf{n}$ & $\%$ & \\
\hline 1 & Tidak Baik & 39 & 56.5 & 30 & 43,5 & 69 & 100 & \multirow{3}{*}{0,04} \\
\hline \multirow[t]{2}{*}{2} & Baik & 17 & $17, .5$ & 80 & 82,5 & 97 & 100 & \\
\hline & Total & 56 & 33.7 & 110 & 66.3 & 166 & & \\
\hline
\end{tabular}

Media konseling yang baik mayoritas 82,5\% menggunakan metode kontrasepsi jangka panjang.

Tabel 3. Tabulasi Silang Pengaruh Metode Konseling Terhadap Ibu Dalam Pemilihan Metode Kontrasepsi Jangka Panjang (MKJP) Di Kelurahan Belawan Bahagia Tahun 2018

\begin{tabular}{|c|c|c|c|c|c|c|c|c|}
\hline \multirow{3}{*}{ No } & \multirow{3}{*}{$\begin{array}{c}\text { Metode } \\
\text { Konseling }\end{array}$} & \multicolumn{4}{|c|}{ Pemilihan KB } & \multirow{2}{*}{\multicolumn{2}{|c|}{ Total }} & \multirow{3}{*}{ p.value } \\
\hline & & \multicolumn{2}{|c|}{ Tidak Menggunakan MKJP } & \multicolumn{2}{|c|}{ Menggunakan MKJP } & & & \\
\hline & & n & $\%$ & n & $\%$ & $\mathbf{n}$ & $\%$ & \\
\hline 1 & Tidak Tepat & 36 & 59,0 & 25 & 41,0 & 61 & 100 & \multirow{3}{*}{0,00} \\
\hline 2 & Tepat & 20 & 19,0 & 85 & 81,0 & 105 & 100 & \\
\hline & Total & 56 & 33.7 & 110 & 66.3 & 166 & & \\
\hline
\end{tabular}

Metode konseling yang tepat mayoritas $81,0 \%$ menggunakan kontrasepsi jangka panjang. Materi penyuluhan konseling yang diterima oleh akseptor KB akan berpengaruh terhadap pengetahuan ibu, dengan materi yang efektif yang diperolehnya, akan berusaha untuk lebih mengetahui tentang kontrasepsi jangka panjang dan lebih berupaya mencari informasi tentang jenis dan manfaat setiap kontrasepsi.Materi akan membuat seseorang ingin lebih mengetahui lebih banyak hal yang diperlukan dan lebih tanggap terhadap informasi serta peka melihat perubahan-perubahan yang terjadi. Materi penyuluhan dapat berbentuk pengalaman misalnya pengalaman bidan yang sukses mengembangkan komoditas tertentu, hasil pengujian/hasil penelitian, keterangan atau kebijakan yang dikeluarkan pemerintah.

\section{CONCLUSION}

Media, materi dan meode konseling berpengaruh terhadap pemilihan metode kontrasepsi jangka panjang. Dalam memberikan konseling sebaiknya meningkatkan kualitas materi, media dan metode yang digunakan.

\section{REFERENCES}

Anggraini, Yetty. (2012). Pelayanan Keluarga Berencana. Yogyakarta: Rohima Press.

Anisah. (2011). Faktor-faktor yang Berhubungan dengan Pemilihan Kontrasepsi Non-IUD pada Akseptor KB pada Wanita Usia 20-39 Tahun di Puskesmas Tlogo Sari Kulon Semarang Timur Tahun 2011.

Badan Pusat Statistik. (2011). Sensus Penduduk Tahun 2010. Jakarta: Badan Pusat Statistik.

BKKBN. (2012). Laporan Akuntabilitas Kinerja Instansi Pemerintah. Jakarta: Badan Kependudukan dan Keluarga Berencana Nasional.

Helfi, Triansih. (2013). Pengaruh Konseling Keluarga Berencana terhadap Pengetahuan dan Niat Pasangan Usia Subur Tentang Kontrasepsi IUD di Wilayah Kerja Puskesmas Blang Mancung Kab. Aceh Tengah Tahun 2013. 
Hidayat, Aziz Alimul. (2010). Metode Penelitian Kesehatan Paradigma Kuantitatif. Surabaya: Health Books Publishing.

Kementerian Koordinator Bidang Kesejahteraan Rakyat. (2013). Penduduk Indonesia jadi 240 juta jiwa. Diakses tanggal 8 februari 2014. URL: http://www.menkokesra.go.id/content/penduduk-indoneisa-jadi240-juta-orang.

Manuaba, Gde, Bagus Ida. (2010). Ilmu Kebidanan, Penyakit Kandungan, dan Keluarga Berencana untuk Pendidikan Bidan. Jakarta: EGC.

Nasir, Abd, Muhith, Ideputri, dkk. (2011). Buku Ajar Metodologi Penelitian Kesehatan. Yogyakarta: Medical Book.

PPLKB Kecamatan Medan Belawan. 2014. Laporan Pelaksanaan KB MKJP. Medan.

Profil Kesehatan Provinsi Sumatera Utara, 2013.

Siswanto, Agus Wilopo. (2010). Tesis: Hubungan Persepsi Klien tentang Konseling Keluarga Berencana dengan Pemakaian Metode Kontrasepsi IUD dan Implant. Yogyakarta: UGM.

Statistik PTKPT. (2013). Jumlah Penduduk di Seluruh Dunia Tahun 2013. Diakses tanggal 20 Juni 2014. URL: http//statistik.ptkpt.net/_a.php?_a=area\&info $1=6$.

Sulistyawati, Ari. (2011). Pelayanan Keluarga Berencana. Jakarta: Salemba Medika.

Suratun. (2008). Pelayanan Keluarga Berencana \& Pelayanan Kontrasepsi. Jakarta: Natawijaya.

Survei Demografi Kesehatan Indonesia. (2012). Badan Kependudukan dan Keluarga Berencana Nasional. Jakarta: Badan Pusat Statistik Kementerian Kesehatan.

Tukiran. (2010). Keluarga Berencana dan Kesehatan Reproduksi. Yogyakarta: Pustaka Pelajar.

Tumini. (2010). Pengaruh Pemberian Konseling Terhadap Pengetahuan tentang KB dan Kemantapan dalam Pemilihan Alat Kontrasepsi pada Calon Akseptor KB Tahun 2010. 